\title{
Megaloblastosis: From Morphos to Molecules
}

\author{
K.C. Das ${ }^{a}$ Monisha Das ${ }^{b}$ \\ D. Mohanty \\ M.M. Jadaon ${ }^{a}$ \\ A. Gupta ${ }^{a}$ \\ R. Marouf ${ }^{a}$ S.K. Easow ${ }^{a}$ \\ ${ }^{a}$ Hematology Unit, Department of Pathology, Faculty of Medicine, Kuwait University, Kuwait; \\ ${ }^{\mathrm{b}}$ Institute of Immunohematology, Mumbai, India
}

\begin{abstract}
Key Words
Megaloblastosis • Electron microscopy •

Chromosomal despiralization - Autoradiography •

${ }^{3} \mathrm{H}$-thymidine incorporation • DNA synthesis •

Deoxyuridine suppression test $\cdot$ Histone biosynthesis
\end{abstract}

\begin{abstract}
Objective: Megaloblastosis (i.e., megaloblastic transformation of erythroid precursor cells in the bone marrow) is the cytomorphological hallmark of megaloblastic anemia resulting from vitamin $B_{12}$ and folate deficiency. It is characterized by a finely stippled lacy pattern of nuclear chromatin, which is believed to be an expression of deranged cellular DNA synthesis. However, the molecular basis of these cytomorphological aberrations still remains obscure. The current presentation describes the results of our studies on some molecular events associated with the development of megaloblastosis. Methods: Transmission electron microscopy was used to study megaloblasts as well as DNA fibers extracted from megaloblastic and normoblastic bone marrows with and without treatment with proteinase $\mathrm{K}$ during the extraction procedure; cellular DNA synthesis in bone marrow cultures was studied by incorporation of ${ }^{3} \mathrm{H}$-thymidine and deoxyuridine suppression test, while histone biosynthesis in bone marrow cells was studied by in vitro incorporation of ${ }^{3} \mathrm{H}$-tryptophan, ${ }^{3} \mathrm{H}$-lysine and ${ }^{3} \mathrm{H}$-arginine into histones. Results: Derangement of DNA syn-
\end{abstract}

thesis occurred due to an impaired de novo pathway of thymidylate synthesis in both vitamin- $B_{12}$ - and folate-deficient human megaloblastic bone marrows as well as in the bone marrows of rhesus monkeys and rats with experimentally induced folate deficiency. Interestingly, folate-deficient monkeys developed frank megaloblastic bone marrows, but folate-deficient rats did not. On the other hand, megaloblastic changes in the bone marrow of human patients with myelodysplastic syndrome and erythroleukemia were not associated with this DNA synthetic abnormality. Biosynthesis of predominantly arginine-rich histones in megaloblastic bone marrows was markedly reduced as compared to normoblastic bone marrows, which was consistently associated with elongation and despiralization of chromosomes and finely stippled nuclear chromatin in megaloblasts. Conclusion: The impaired biosynthesis of predominantly argininerich nuclear histones appeared to be a common molecular event (a denominator) underlying the development of megaloblastosis with or without abnormal DNA synthesis.

Copyright (C) 2005 S. Karger AG, Basel

\section{Introduction}

Megaloblastic anemia is essentially recognized as a morphological entity and is characterized by megaloblastic transformation of erythroid precursor cells in the bone

\section{KARGER}

Fax +4161306 1234

E-Mail karger@karger.ch

www.karger.com
(C) 2005 S. Karger AG, Basel

$1011-7571 / 05 / 0147-0002 \$ 22.00 / 0$

Accessible online at:

www.karger.com/mpp
Dr. K.C. Das

Hematology Unit, Department of Pathology, Faculty of Medicine, Kuwait University PO Box 24923, 13110 Safat (Kuwait)

Tel. +965 531 9476, Fax +965 5338905

E-Maildrkcdas@hotmail.com, kshitish@hsc.edu.kw 
marrow of these patients. Megaloblastosis is the cytomorphological diagnostic marker of megaloblastic anemia, and represents a unique morphological and functional aberration of erythropoiesis. Megaloblasts are characterized by several cytomorphological features which are distinct from those of normal erythroid precursor cells (i.e., normoblasts) at all stages of maturity. These include larger cell size, and a finely stippled, open lacy pattern of nuclear chromatin. The cytoplasmic features are less remarkable, with evident asynchrony between nuclear and cytoplasmic maturation. The original prototype of this anemia was Addisonian pernicious anemia, initially recognized in the Caucasians as the only example of megaloblastic anemia in the nineteenth century. It was later discovered that this anemia was caused by a deficiency of vitamin $B_{12}$ due to a lack of its obligatory binder gastric intrinsic factor and consequent malabsorption of this vitamin [1]. Lucy Wills $[2,3]$ described for the first time another type of megaloblastic anemia, the 'pernicious anemia of pregnancy' and 'tropical macrocytic anemia', which were later found to be due to a deficiency of folate (folic acid). It is, however, not infrequent to find strict vegetarians and vegans in the Indian subcontinent (either due to religious and social compulsions, food faddism or poverty) who develop vitamin $\mathrm{B}_{12}$ deficiency and megaloblastic anemia even when gastric intrinsic factor is not deficient $[4,5]$. Common causes of megaloblastic anemias are deficiency of vitamin $\mathrm{B}_{12}$ and folate due to various reasons such as poor dietary intake, malabsorption, increased requirement, utilization and excretion [6]. Cytomorphological changes very similar to megaloblastosis can also occur in erythroid precursor cells in the bone marrow of patients with myelodysplastic syndrome and erythroleukemia; these latter conditions are relatively rare, and the nature of these 'megaloblastic' changes remains obscure. Whereas vitamin- $\mathrm{B}_{12^{-}}$and folate-deficient megaloblastic anemias are successfully treated by providing the deficient vitamins (i.e., folic acid or vitamin $\mathrm{B}_{12}$ ), 'megaloblastic' changes associated with myelodysplastic syndrome and erythroleukemia are resistant to treatment with these vitamins. Megaloblastic changes caused by vitamin $\mathrm{B}_{12}$ and folate deficiency appear to be systemic processes not restricted to the cells of the erythroid series, but affecting all replicating cells [1, 7-9]. The appearance of giant metamyelocytes and hypersegmented neutrophils in vitamin- $\mathrm{B}_{12^{-}}$and folate-deficient megaloblastic anemias are also believed to be cytomorphological expressions of these vitamin deficiencies $[1,9]$.
When peripheral blood lymphocytes of patients with vitamin- $\mathrm{B}_{12^{-}}$or folate-deficient megaloblastic anemias are stimulated by a mitogen such as phytohemagglutinin in tissue cultures, they undergo 'blastic' transformation, but the cytomorphological features of these transformed lymphoblasts are different from similarly transformed lymphoblasts from normal subjects. The transformed lymphoblasts from megaloblastic anemia patients are generally larger, possess finely stippled nuclear chromatin, and also develop a DNA synthetic abnormality as revealed by an abnormal or impaired de novo pathway of thymidylate synthesis. They have been described as 'megaloblastic lymphocytes' $[10,11]$. The cytomorphological changes in megaloblastic erythroid precursor cells and other replicating cell systems are generally believed to be morphological expressions of a poorly defined derangement of cellular DNA synthesis [7, 10-12]. This hypothesis has not since been adequately explored or verified in clinical or experimental conditions.

The current presentation is based on our studies on cytomorphological features and molecular events in human megaloblastic bone marrows, and in the bone marrows of two mammalian species (i.e., rhesus monkeys and Wistar strain rats) rendered folate deficient by dietary deprivation of folate. These studies included (a) cytomorphological studies of human megaloblastic bone marrows with particular focus on nuclear chromatin; (b) cytogenetic analysis for chromosomal pattern and replication; DNA content, DNA synthesis and deoxyuridine (dU) suppression test; (c) cytomorphological features, DNA synthesis and dU suppression test in the bone marrows of folate-deficient monkeys and rats, and (d) histone biosynthesis in megaloblastic and control (normoblastic) bone marrows.

\section{Materials and Methods}

\section{Human Subjects}

This study was carried out on 50 patients with megaloblastic anemia of moderate to severe degree (table 1). Among them, 40 had vitamin $B_{12}$ deficiency ( 25 had pernicious anemia with positive Schilling's test, parietal cell antibodies and intrinsic factor antibodies, whereas 15 had nutritional deficiency of vitamin $B_{12}$, being vegetarian or vegans) and 10 had folate deficiency as indicated by subnormal serum and red cell folate levels either due to poor folate intake or malabsorption. There were 15 patients with myelodysplastic syndrome, who presented with persistent pancytopenia, and macrocytic red cells with a few hypolobulated and hypogranular neutrophils (pseudo-Pelger anomaly). Their bone marrows showed normocellularity or hypercellularity and varying degrees of dysplastic changes involving two or more cell lines; the erythroid precursor cells in their bone marrows showed significant, but varying degrees 
Table 1. Basic hematological profile of 50 patients with megaloblastic anemia and 30 control subjects

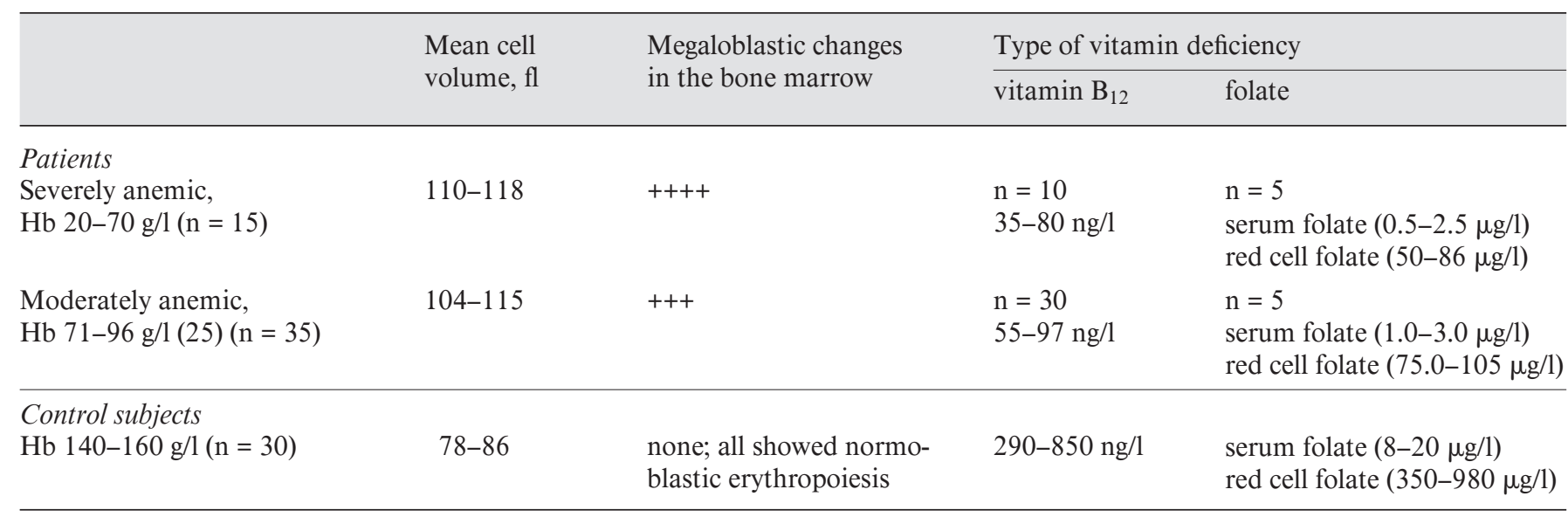

Table 2. Folate levels in serum, red cells and liver before and after feeding rats and rhesus monkeys on folate-poor diet

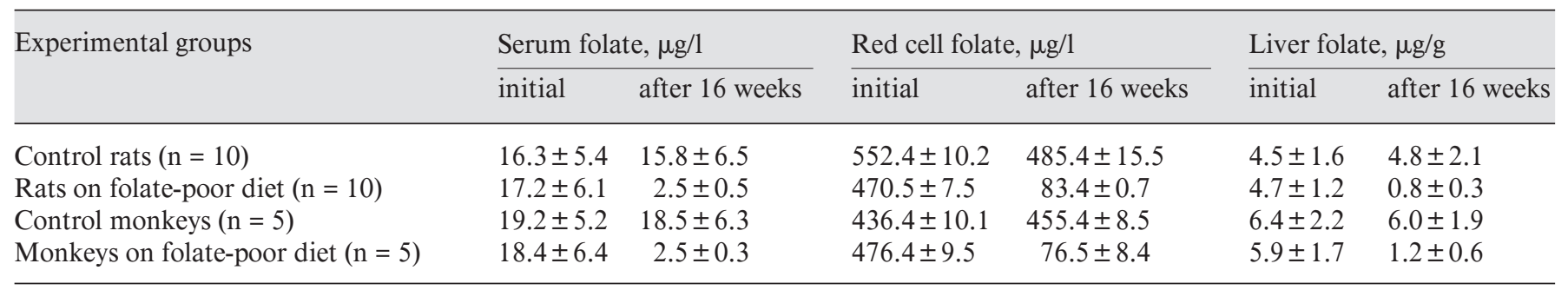

of megaloblastic changes. There were 5 patients with erythroleukemia (AML, M6), which were diagnosed by their peripheral blood count, bone marrow cytomorphology, cytochemical features and immunophenotyping characteristics; their bone marrows showed megaloblastic changes. Thirty subjects aged 10-40 years, who were hematologically normal, but had undergone bone marrow examination for unrelated disorders to exclude metabolic disorders (e.g. Gaucher's disease, Niemann-Pick's disease), or for chromosomal studies to exclude chromosomal mosaic, were studied as controls. Bone marrow aspiration and trephine biopsies were performed after obtaining informed consents. Twenty patients with moderate to severe iron deficiency anemia were studied for histone biosynthesis in the bone marrow and compared with those with megaloblastic anemia.

\section{Experimental Folate Deficiency}

Folate deficiency was produced in two mammalian species: (a) higher mammal: rhesus monkeys; (b) lower mammal: Wistar strain rats.

Folate Deficiency in Rhesus Monkeys. Five adult healthy rhesus monkeys (Macaca mulatta) each weighing 5-6 kg were caged individually in a well-lighted room, acclimatized to the laboratory conditions for 6-8 weeks. Folate deficiency was produced in these animals by feeding them a folate-deficient diet through a Ryle's tube as described by us previously [13]. Another 5 monkeys were separately caged and were fed a folate-rich diet (containing $100 \mu \mathrm{g}$ folic acid per $100 \mathrm{~g}$ of the diet) to serve as the control group. The development of folate deficiency was monitored by measuring the levels of folate in the serum, red cells and finally in the liver. The monkeys fed a folate-poor diet showed consistent evidences of development of folate deficiency in 16-20 weeks, whereas the animals fed a folate-rich diet (the control group) showed no deficiency (table 2). At the end of the experiments, the monkeys were anesthetized, and in addition to collecting blood samples, bone marrows were aspirated from the posterior iliac spine for morphological studies, short-term tissue cultures, DNA synthesis, dU suppression test and other biochemical analyses.

Folate Deficiency in Rats. Folate deficiency was produced in 10 weanling (4 weeks old) Wistar strain rats weighing about 50-60 g each. Each rat was kept in a separate cage. Folate deficiency was produced by feeding them a folate-deficient diet as described previously $[13,14]$. Another 10 rats of similar age, sex and weight were separately caged to serve as the control group. The control animals were pair-fed with an isocaloric, folate-rich diet containing $50 \mathrm{mg}$ of folic acid per kilogram of the diet; the folate-deficient diet contained no measurable folic acid content. Preliminary experiments showed that the rats fed on this deficient diet developed folate deficiency after 12-16 weeks. This was indicated by consistently low 
levels of folate in the serum, red cells and the liver in these animals, whereas the control animals showed no significant decrease in folate levels (table 2). At the end of the experiments, the rats were anesthetized by administering anesthetic ether and sacrificed. The bone marrows were taken from the femur and processed for morphology, short-term tissue culture, DNA synthesis and dU suppression test and other biochemical analyses.

\section{Hematological Studies}

Routine hematological studies were performed by standard techniques [15]. Blood and bone marrow smears were stained by May-Grünwald-Giemsa stain for cell morphology.

\section{Transmission Electron Microscopy of Human Bone Marrow Cells}

Briefly, the following procedure was used. Aspirated bone marrow cells were collected in balanced salt solution, centrifuged to make a cell button, which was fixed in $3.0 \%$ glutaraldehyde solution for 2-3 h, washed in Millonig's buffer, $\mathrm{pH} 7.3$, and then treated with $1.0 \%$ osmium tetroxide, washed again in Millonig's buffer for $3 \mathrm{~h}$, appropriately dehydrated in increasing concentrations of ethanol and dried in absolute ethanol, then put in two changes of propylene oxide for 10 min each, and finally blocks were made in pure epoxy resin, from which ultra-thin sections were finally made for transmission electron microscopy in a JEOL 1200 EX.

\section{DNA Synthesis and dU Suppression Test}

A portion of the aspirated bone marrow was collected aseptically in cold heparinized $0.06 \mathrm{M}$ Tris-buffered Hank's balanced salt solution, $\mathrm{pH} 7.4$, and processed into a monolayered suspension for short-term culture; DNA synthesis was monitored by measuring incorporation of ${ }^{3} \mathrm{H}$-thymidine $\left({ }^{3} \mathrm{H}-\mathrm{TdR}\right)$ into DNA, and dU suppression test was done as described by us previously [16, 17]. The dU suppression values were calculated as follows:

\footnotetext{
Percentage due suppression $=$

${ }^{3} \mathrm{H}-\mathrm{TdR}$ incorporation into DNA with dU

$\frac{{ }^{3} \mathrm{H}-\mathrm{TdR} \text { incorporation into DNA without dU }}{100}$
}

dU suppression correction by the additions of folates or vitamin $\mathrm{B}_{12}=$

${ }^{3} \mathrm{H}-\mathrm{TdR}$ incorporation into DNA with dU and folate and/or vitamin $\mathrm{B}_{12}$

${ }^{3} \mathrm{H}-\mathrm{TdR}$ incorporation into DNA without $\mathrm{dU}$ $\times 100$

${ }^{3} \mathrm{H}-\mathrm{TdR}$ incorporation into cellular DNA is a sensitive radionucleoside marker of DNA synthesis. The generation of deoxythymidine monophosphate (dTMP) and then deoxy-thymidine triphosphate $(\mathrm{dTMP} \rightarrow \mathrm{dTTP})$ is of particular importance for this synthetic process due to relative specificity of the thymine base in the composition of DNA (fig. 8). The dU suppression test essentially measures the efficacy of the de novo pathway by studying the incorporation of ${ }^{3} \mathrm{H}-\mathrm{TdR}$ into DNA (via the salvage pathway) in the presence of a standardized excess of dU added to the short-term tissue culture of bone marrow cells. Normally, the deoxyuridylate (dUMP) suppresses the incorporation of ${ }^{3} \mathrm{H}-\mathrm{TdR}$ into cellular DNA to $10 \%$ of control cultures (i.e., cultures without added dU). In deficiency of folate and vitamin $\mathrm{B}_{12}$, the de novo pathway is relatively inactive as a result of which the added dU fails to sup- press the incorporation of ${ }^{3} \mathrm{H}-\mathrm{TdR}$ into DNA (i.e., ${ }^{3} \mathrm{H}-\mathrm{TdR}$ incorporation is higher than $10 \%$ of the control). The higher the dU suppression value, the more inactive or inefficient is the de novo pathway. This abnormality can be corrected to $10 \%$ or less of dUsuppressed values by the addition of the deficient vitamins (folate or vitamin $\mathrm{B}_{12}$ ). While all folates including 5-methyl-tetrahydrofolate (THF) completely correct the dU suppression abnormality due to folate deficiency, a combination of vitamin $\mathrm{B}_{12}$ and 5-methylTHF is required to correct the abnormality in vitamin $\mathrm{B}_{12}$ deficiency $[6,10,15]$.

The incorporation of ${ }^{3} \mathrm{H}-\mathrm{TdR}$ into individual cells was studied by autoradiography as described by us previously [18]. DNA content of individual cells in the bone marrow smears was measured after Feulgen staining in a Becton-Dickinson Cellular Imaging System (CAS 200). Cytogenetic analysis was done as previously described by us [19].

Extraction and isolation of DNA from bone marrow cells were done by the classical phenol-chloroform extraction method as described by Sambrook et al. [20]. Replicate samples from each bone marrow were subjected to treatment with proteinase $\mathrm{K}$ during the extraction procedure in order to remove the nuclear proteins such as histones from the DNA, whereas the other sample from each bone marrow was not treated with proteinase K. The DNA fibers were precipitated and dehydrated in ethanol and air-dried. These fibers were then fixed in 3.0\% glutaraldehyde, washed in Millonig's buffer, dehydrated in ethanol and finally embedded in epoxy resin, and ultra-thin sections were made for transmission electron microscopy.

\section{Histone Content and Histone Biosynthesis in Bone Marrow \\ Cells}

Histone content was measured and its biosynthesis studied by methods previously described [21-24]. The incorporations of ${ }^{3} \mathrm{H}$-tryptophan, ${ }^{3} \mathrm{H}$-lysine and ${ }^{3} \mathrm{H}$-arginine into bone marrow cells in vitro were used as radioactive tracers for biosynthesis of histones.

\section{Serum and Red Cell Folate and Vitamin $B_{12}$}

Serum and red cell folate and vitamin $B_{12}$ were estimated by radioisotope dilution techniques using appropriate binders for these two vitamins as described previously $[25,26]$.

\section{Statistical Method}

Statistical package for Social Sciences (SPSS Inc., Chicago, Ill., USA) was used for data processing; a $p$ value $\leq 0.05$ was used as cutoff level of significance. Student's t test was used for comparing means.

\section{Results}

\section{Cytomorphological Changes in Blood and Bone}

Marrows

The patients with megaloblastic anemia due to deficiency of vitamin $B_{12}$ or folate had variable degrees of anemia from moderate to severe, with or without thrombocytopenia or leukopenia (table 1). Macrocytosis and macro-ovalocytosis of red cells and hypersegmented neu- 

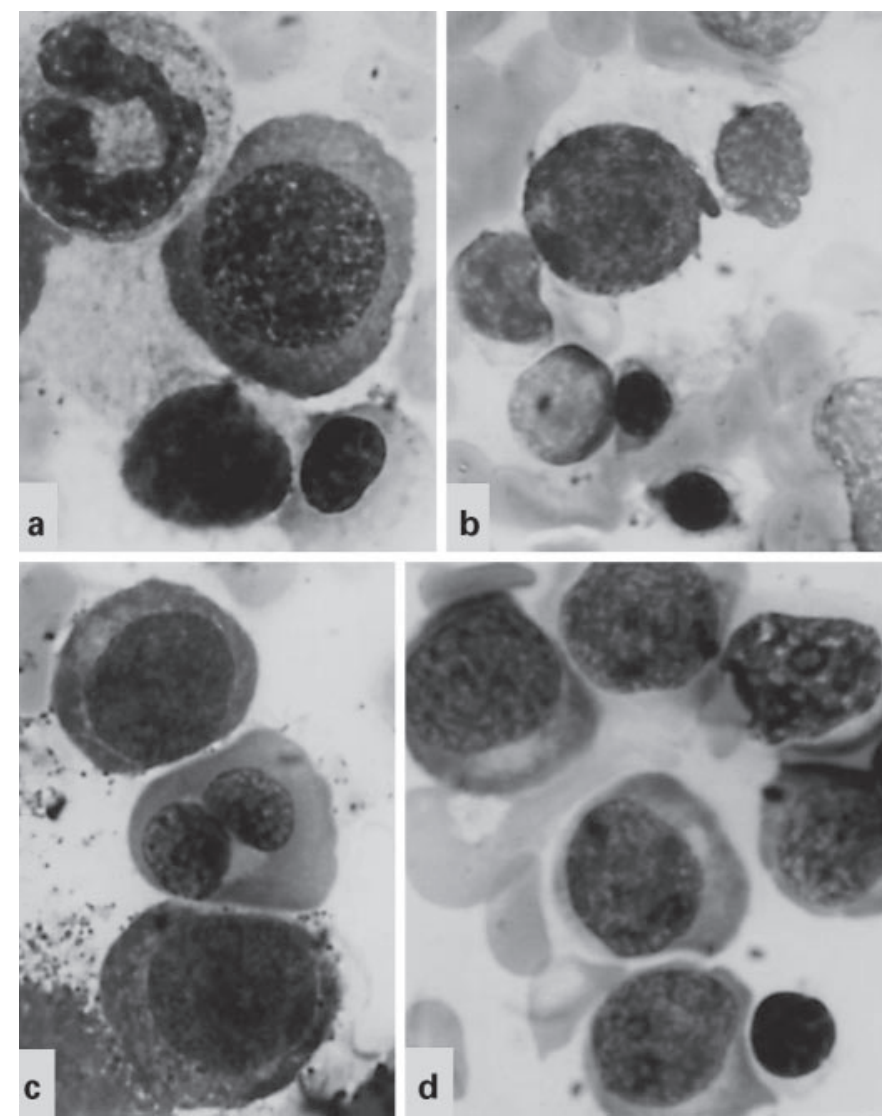

Fig. 1. Light microscopic cytomorphological features of megaloblasts (a) and normoblasts (b). Megaloblasts show relatively larger cell size, a finely stippled lacy pattern of nuclear chromatin, with asynchrony between nuclear and cytoplasmic maturation. In contrast, normoblasts show condensed and clumpy nuclear chromatin. Bone marrows from patients with myelodysplastic syndrome (c) and erythroleukemia (d) also show megaloblastic changes.

trophils were predominant morphological changes in peripheral blood. The bone marrow smears from the aspirates showed frank megaloblastosis of erythroid precursor cells, which were mainly characterized by larger cell size, and a finely stippled lacy pattern of nuclear chromatin, with relatively abundant cytoplasm and asynchrony between nuclear and cytoplasmic maturity (fig. 1a) as compared to normoblasts (from bone marrows of control subjects) (fig. 1b). The erythroid precursor cells in the bone marrow of patients with myelodysplastic syndrome and erythroleukemia also displayed variable degrees of immaturity of nuclear chromatin showing a finely stippled lacy pattern (fig. 1c, d), resembling the megaloblasts in vitamin- $\mathrm{B}_{12^{-}}$or folate-deficient megaloblastic anemia.
Table 3. Results of autoradiographic studies for incorporation of ${ }^{3} \mathrm{H}-\mathrm{TdR}$ into DNA in bone marrow cells in vitro

\begin{tabular}{lcl}
\hline & $\begin{array}{l}\text { Labeling } \\
\text { index }\end{array}$ & $\begin{array}{l}\text { Mean } \\
\text { grain count }\end{array}$ \\
\hline $\begin{array}{c}\text { Basophilic + polychromatic } \\
\text { normoblasts }\end{array}$ & $25 \pm 6.7$ & $21.57 \pm 5.3$ \\
$\begin{array}{c}\text { Basophilic + polychromatic } \\
\text { megaloblasts }\end{array}$ & $51.3 \pm 8.2^{*}$ & $43.6 \pm 8.7^{*}$ \\
\hline
\end{tabular}

Control subjects: $\mathrm{n}=30$; vitamin- $\mathrm{B}_{12}$-deficient subjects: $\mathrm{n}=40$; folate-deficient subjects: $\mathrm{n}=10 . * \mathrm{p} \leq 0.01$ compared to the normal values.

\section{Transmission Electron Microscopy}

These cytomorphological differences between the normoblasts and megaloblasts appeared magnified in the transmission electron microscopy with particular reference to the spongy, finely stippled appearance of the nuclear chromatin in the megaloblasts in contrast to condensed chromatin in the nuclei of normoblasts (fig. 2a-d).

\section{Cytogenetic Studies}

No significant numerical changes were observed; the model number of chromosomes was 46 and a very small number of metaphase plates showed random aneuploidy. However, the individual chromosomes showed striking structural changes, which were characterized by elongation and despiralization of chromosomes (fig. 3a, b); occasional polyploidy and endoreduplication were encountered. The replication pattern of chromosomes in megaloblastic anemia also appeared different from normoblastic bone marrows as studied by autoradiography after incorporation of ${ }^{3} \mathrm{H}-\mathrm{TdR}$ into DNA (fig. 4a, b).

\section{Cellular DNA Content, and DNA Synthesis \\ (i.e., ${ }^{3} \mathrm{H}-\mathrm{TdR}$ Incorporation into DNA)}

The measurement of DNA content of megaloblasts and normoblasts by image analysis after Feulgen staining showed that the interphase $(\mathrm{Go} / \mathrm{G} 1)$ cells constituted the majority with modal DNA content of diploid cells (fig. 2c). A relatively small proportion of the cell population $(<10 \%)$ showed random aneuploidy on either side of the diploid mode. Autoradiographic studies after $1 \mathrm{~h}$ of pulse exposure to ${ }^{3} \mathrm{H}-\mathrm{TdR}$ in short-term culture of bone marrow cells showed that the labeling index as well as grain count of basophilic and polychromatic erythroblasts were significantly higher in the megaloblastic bone marrows than in the normal bone marrows (table 3); the orthochromatic 
Fig. 2. Transmission electron microscopic picture of normoblasts (a, b) shows condensed and clumpy chromatin; in contrast, transmission electron microscopic picture of megaloblasts $(\mathbf{c}, \mathbf{d})$ shows well-dispersed finely stippled rarefied nuclear chromatin.

Fig. 3. A metaphase plate from bone marrow of a control (normal) subject (a) and from a patient with megaloblastic anemia (b) showing elongation and despiralization of individual chromosomes.

Fig. 4. Autoradiographic study of chromosomal preparations after ${ }^{3} \mathrm{H}-\mathrm{TdR}$ incorporation showing the distribution pattern of silver grains due to ${ }^{3} \mathrm{H}-\mathrm{TdR}$ uptake in normal (a) and megaloblastic chromosomes (b).
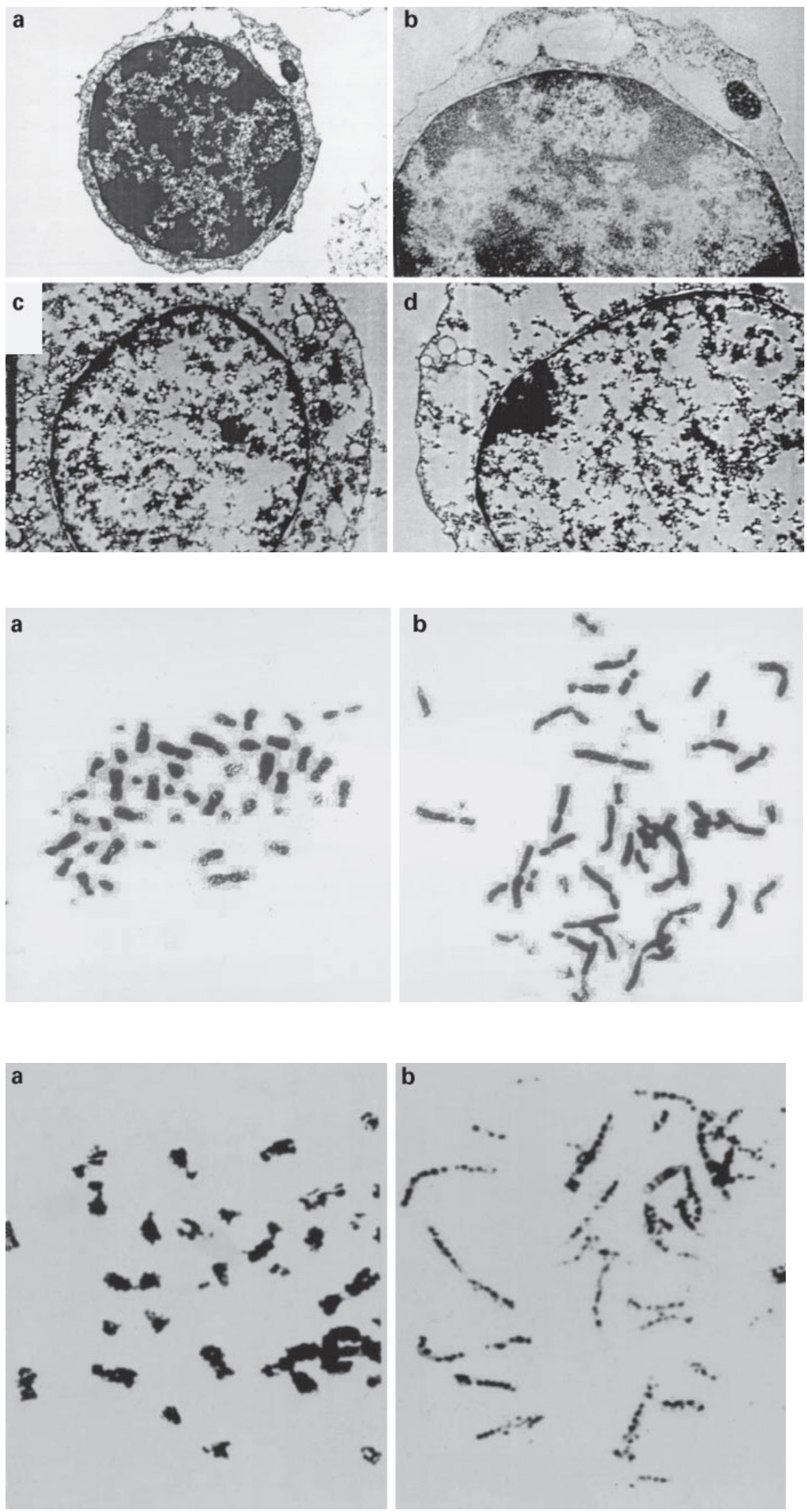


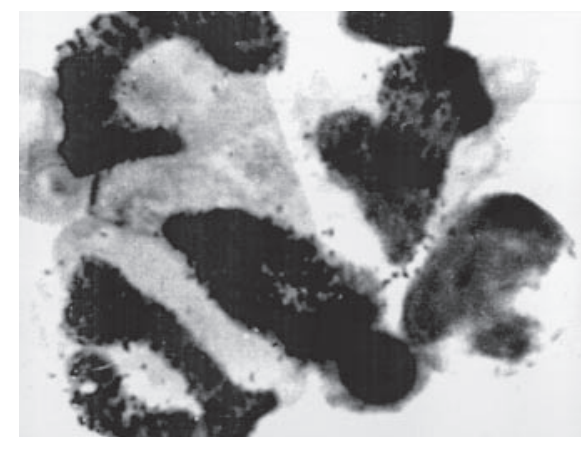

Fig. 5. Autoradiography of megaloblastic bone marrows showing ${ }^{3} \mathrm{H}-\mathrm{TdR}$-labeled giant metamyelocytes indicating their proliferative ability.

erythroblasts did not take up ${ }^{3} \mathrm{H}-\mathrm{TdR}$ as these cells do not proliferate. The cells of granulocytic series in megaloblastic anemia also showed relative slowing of maturation. The metamyelocytes in the control bone marrows did not incorporate ${ }^{3} \mathrm{H}-\mathrm{TdR}$, but giant metamyelocyte in the megaloblastic bone marrow showed incorporation of ${ }^{3} \mathrm{H}-\mathrm{TdR}$ into DNA, indicating its proliferative ability (fig. 5).

\section{$d U$ Suppression Test}

The results of $\mathrm{dU}$ suppression tests in human bone marrows are shown in table 4 . This has proved to be a very sensitive test to detect and quantitate megaloblastosis due to deficiency of folate and vitamin $B_{12}$, even in very mild or early clinical states when morphological manifestations remain equivocal [7, 10-12, 16, 17]. Furthermore, the dU suppression test was found to be normal when performed with bone marrows of patients with myelodysplastic syndrome and erythroleukemia (table 4) in which cytomorphological changes very similar to megaloblastosis also occurred.

Morphology and DNA Synthesis in the Bone Marrows of Folate-Deficient Animals

Folate-Deficient Rhesus Monkeys. Five adult monkeys fed a folate-poor diet for 4-5 months developed hematological and biochemical evidences of folate deficiency. They developed mild to moderate anemia and thrombocytopenia with or without leukopenia. The peripheral blood smear showed macrocytic red cells and hypersegmented neutrophils. Serum and red cell folate as well as liver folate were markedly reduced as compared to the control monkeys, which were fed a folate-rich diet (table 2). The serum vitamin $B_{12}$ levels remained normal.
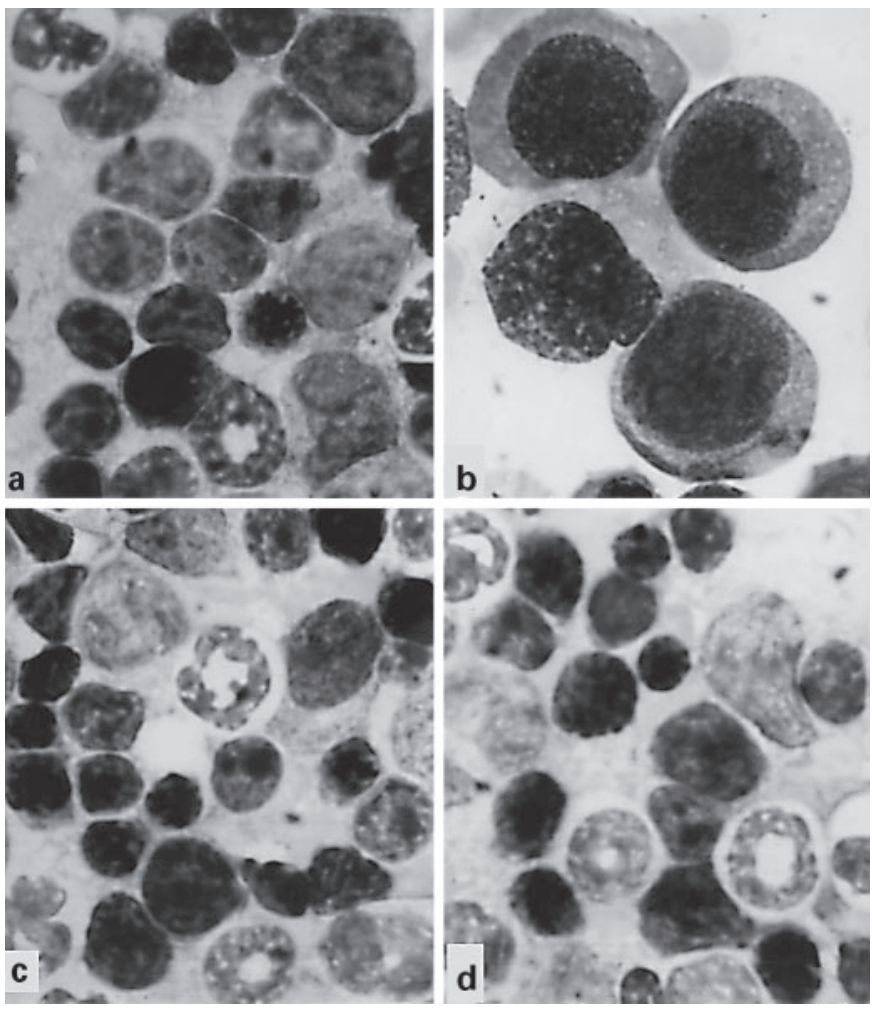

Fig. 6. a A bone marrow smear from a control rhesus monkey showing normoblastic erythropoiesis. b A bone marrow smear from a folate-deficient rhesus monkey showing florid megaloblastic transformation. c A bone marrow smear from a control rat showing normoblastic erythropoiesis. d A bone marrow smear from an established folate-deficient rat showing normoblastic erythropoiesis. Absence of megaloblastic transformation.

The bone marrow smears of the control monkeys fed a folate-rich diet showed normoblastic erythropoiesis (fig. 6a), whereas the folate-deficient monkeys revealed frank megaloblastic transformation (fig. 6b). The dU suppression test of their aspirated bone marrows showed abnormal results, which were corrected in vitro by the addition of 5-methyl-THF but not by vitamin $\mathrm{B}_{12}$ (table 5). All of these features were similar to those of human megaloblastic anemia due to folate deficiency.

Folate-Deficient Rats. Weanling Wistar rats fed a folate-poor diet developed persistently low levels of folate in their serum, red cells and liver in 12-16 weeks (table 2). They also developed mild to moderate anemia, thrombocytopenia and leukopenia, but red cells were still normocytic and normochromic. The bone marrow smears of control rats (fig. 6c) as well as of folate-deficient rats (fig. 6d) showed normoblastic erythropoiesis (i.e., ab- 
Table 4. Summary of results of dU suppression tests in short-term cultures of bone marrow cells

\begin{tabular}{lccccc}
\hline & dU alone & $\begin{array}{l}\text { dU + 5-me- } \\
\text { thyl-THF }\end{array}$ & $\begin{array}{l}\text { dU + } \\
\text { CNC bl }\end{array}$ & $\begin{array}{l}\text { dU + CNC bl + } \\
\text { 5-methyl-THF }\end{array}$ & $\begin{array}{l}\mathrm{dU}+ \\
\text { folic acid }\end{array}$ \\
\hline Normal $(\mathrm{n}=30)$ & $7.5 \pm 2.2$ & $6.8 \pm 1.8$ & $7.1 \pm 2.0$ & $8.5 \pm 2.3$ & $9.0 \pm 1.4$ \\
Vitamin $\mathrm{B}_{12}$ deficient* $(\mathrm{n}=40)$ & $75.5 \pm 15.0$ & $59.6 \pm 12.7$ & $46.5 \pm 15.2$ & $9.2 \pm 3.2$ & $8.6 \pm 2.4$ \\
Folate deficient* $(\mathrm{n}=10)$ & $63.8 \pm 18.5$ & $8.9 \pm 3.2$ & $61.9 \pm 21.0$ & $7.5 \pm 1.8$ & $9.0 \pm 2.1$ \\
Myelodysplastic syndrome $(\mathrm{n}=15)$ & $7.2 \pm 1.8$ & $9.3 \pm 2.4$ & $6.9 \pm 2.1$ & $7.7 \pm 2.5$ & $8.2 \pm 2.0$ \\
Erythroleukemia $(\mathrm{n}=5)$ & $9.5 \pm 2.6$ & $6.8 \pm 1.9$ & $7.5 \pm 2.3$ & $8.2 \pm 2.2$ & $7.4 \pm 1.6$ \\
\hline
\end{tabular}

dU suppression values expressed as percentage incorporation of ${ }^{3} \mathrm{H}-\mathrm{TdR}$ into DNA without dU (see sections on Methods). $\mathrm{CNC}$ bl = cyanocobalamin.

$* \mathrm{p}<0.01$ compared with normal values. The values for myelodysplastic syndrome and erythroleukemia were not significant compared to the normal values. Results are means $\pm \mathrm{SD}$.

Table 5. Results of dU suppression test in folate-deficient rats and rhesus monkeys

\begin{tabular}{lcccc}
\hline & $\mathrm{dU}$ alone & $\begin{array}{l}\mathrm{dU}+ \\
\text { folic acid }\end{array}$ & $\begin{array}{l}\mathrm{dU}+ \\
\text { 5-methyl-THF }\end{array}$ & $\begin{array}{l}\mathrm{dU}+ \\
\text { vitamin } \mathrm{B}_{12}\end{array}$ \\
\hline Control rats $(\mathrm{n}=10)$ & $10.2 \pm 8.2$ & $9.2 \pm 2.6$ & $9.5 \pm 2.2$ & $8.6 \pm 2.8$ \\
Folate-deficient rats $(\mathrm{n}=10)$ & $38.5 \pm 8.5^{*}$ & $9.8 \pm 3.0^{*}$ & $8.9 \pm 2.8^{*}$ & $40.5 \pm 12.5^{*}$ \\
Control monkeys $(\mathrm{n}=5)$ & $9.1 \pm 2.2$ & $10.1 \pm 2.5$ & $8.6 \pm 1.8$ & $7.9 \pm 3.3$ \\
Folate-deficient monkeys $(\mathrm{n}=5)$ & $52.6 \pm 15.6^{*}$ & $9.8 \pm 3.5^{*}$ & $10.0 \pm 2.9^{*}$ & $49.5 \pm 11.8^{*}$ \\
\hline
\end{tabular}

$\mathrm{dU}$ suppression values are expressed as percentage of ${ }^{3} \mathrm{H}-\mathrm{TdR}$ incorporation into DNA $\left({ }^{3} \mathrm{H}-\mathrm{TdR}\right.$ incorporation in replicate cultures without dU is taken as $100 \%)$.

$* \mathrm{p}<0.01$; folate-deficient rats compared with control rats and folate-deficient monkeys compared with control monkeys.

sence of megaloblastic transformation). DNA synthesis as indicated by dU suppression test was abnormal or impaired, which was corrected by the addition of methylTHF, not by vitamin $B_{12}$ (table 5).

\section{Transmission Electron Microscopy of DNA Fibers} from Human Patients with Megaloblastic Anemia and from Control Subjects

DNA fibers from normoblastic bone marrows (i.e., bone marrows of control subjects) after extraction without proteinase $\mathrm{K}$ appeared tightly knotted or beaded at regular intervals yielding a wavy pattern (fig. 7a). When DNA was extracted from these cells with proteinase K, which removed nuclear proteins including histone, the DNA fibers appeared straight, elongated with disappearance of the knots and the wavy pattern (fig. 7b). On the other hand, DNA fibers extracted from megaloblastic bone marrow cells without proteinase $\mathrm{K}$ showed very few or no beads and knots and consequently looked relative- ly straightened and relaxed (fig. 7c) and comparable to the DNA fibers extracted from these cells using proteinase $\mathrm{K}$ (fig. 7d), suggesting that megaloblasts had a markedly reduced nuclear histone content.

\section{Histone Biosynthesis in the Bone Marrows of Control Subjects and Patients}

The incorporation of the radioactive amino acid ${ }^{3} \mathrm{H}-$ tryptophan is a marker of total histone biosynthesis, whereas the incorporation of ${ }^{3} \mathrm{H}$-lysine occurs preferentially into lysine-rich histones (i.e., $\mathrm{H}_{1}, \mathrm{H}_{2} \mathrm{~A}$, and $\mathrm{H}_{2} \mathrm{~B}$ histones), and that of ${ }^{3} \mathrm{H}$-arginine into arginine-rich histones (i.e., $\mathrm{H}_{3}$ and $\mathrm{H}_{4}$ histones). The results of these studies are shown in table 6 . There was a decrease in total histone synthesis in the folate- and vitamin- $B_{12}$-deficient megaloblastic bone marrows as compared to those of controls and iron deficiency anemia. This defect appeared to have predominantly affected the synthesis of argininerich histones. Similar impairment of histone biosynthe- 
Fig. 7. Transmission electron microscopic picture of DNA fibers from a control (normal) bone marrow without proteinase $\mathrm{K}$ treatment showing knotted and spiral wavy pattern (a); DNA fiber from the control (normal) bone marrow after extraction with proteinase $\mathrm{K}$ to remove nuclear proteins (e.g. histones) showing that DNA fibers lost their knotted, beaded appearance and appeared relaxed and straight $(\mathbf{b})$, from the bone marrow of a patient with megaloblastic anemia without proteinase $\mathrm{K}$ treatment during extraction (c), and with proteinase $\mathrm{K}$ treatment (d); both $\mathbf{c}$ and $\mathbf{d}$ showed loss of knots and wavy pattern resulting in despiralized and relaxed appearance of the fibers, suggesting absence or reduction of nuclear histones in the DNA of megaloblasts. a Without proteinase $\mathrm{K}$

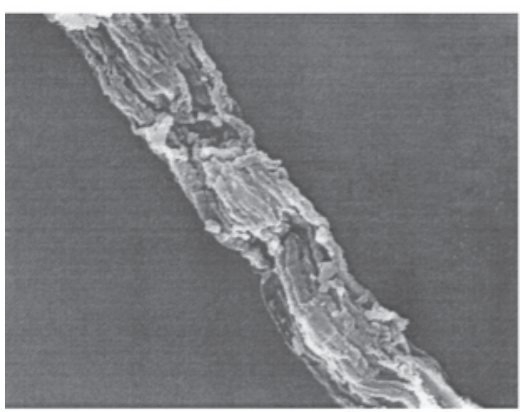

c Without proteinase $\mathrm{K}$

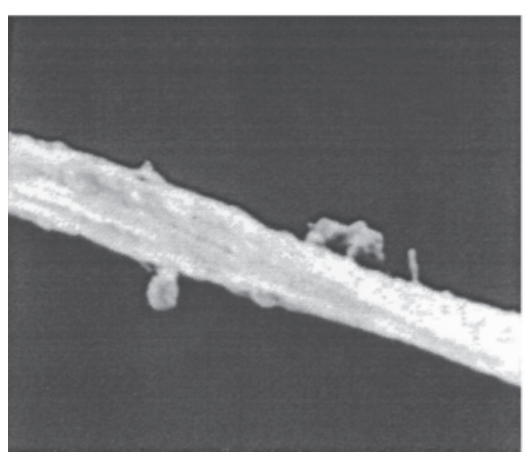

b With proteinase $\mathrm{K}$

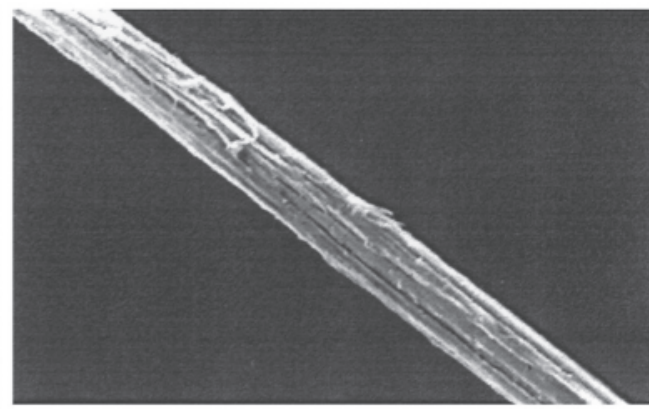

d With proteinase $\mathrm{K}$

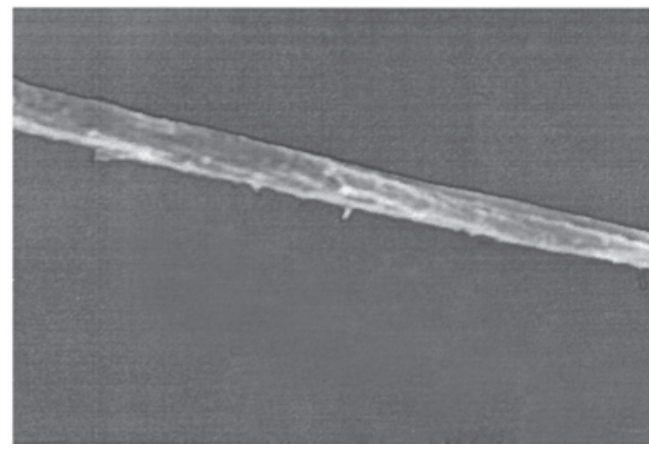

Table 6. The incorporation of ${ }^{3} \mathrm{H}$-tryptophan, ${ }^{3} \mathrm{H}$-lysine and ${ }^{3} \mathrm{H}$-arginine into nuclear histones

\begin{tabular}{llcr}
\hline & ${ }^{3}$ H-tryptophan & ${ }^{3}$ H-lysine & ${ }^{3}$ H-arginine \\
\hline Control subjects $(\mathrm{n}=20)$ & $21,500 \pm 1,510$ & $11,448 \pm 1,200$ & $10,175 \pm 1,125$ \\
Iron deficiency anemia $(\mathrm{n}=20)$ & $22,054 \pm 1,325$ & $10,955 \pm 1,175$ & $10,115 \pm 1,096$ \\
Vitamin-B $_{12}$-deficient megaloblastic anemia $(\mathrm{n}=30)$ & $16,455 \pm 1,024^{*}$ & $7,995 \pm 875^{*}$ & $2,785 \pm 615^{* *}$ \\
Folate-deficient megaloblastic anemia $(\mathrm{n}=10)$ & $15,145 \pm 1,086^{*}$ & $8,155 \pm 920^{*}$ & $3,225 \pm 865^{* *}$ \\
Erythroleukemia $(\mathrm{n}=5)$ & $17,508 \pm 512^{*}$ & $9,526 \pm 726^{*}$ & $5,868 \pm 497^{*}$ \\
Myelodysplastic syndrome $(\mathrm{n}=15)$ & $16,973 \pm 995^{*}$ & $8,972 \pm 698^{*}$ & $6,287 \pm 586^{*}$
\end{tabular}

The figures indicate the radioactivity (disintegrations per minute) incorporated. Results are means \pm SD.

$* \mathrm{p}<0.05 ; * * \mathrm{p}<0.01$, compared to control subjects.

sis, particularly of arginine-rich histones, was also observed in the bone marrow of patients with myelodysplastic syndrome and erythroleukemia.

\section{Discussion}

Several hematological conditions are known to be associated with megaloblastic changes in the bone marrow. The most common among these are deficiency of vitamin
$\mathrm{B}_{12}$ and folate, resulting in megaloblastic anemia, which can be completely corrected or cured by treating them with the deficient vitamins. Megaloblastic changes also occur in the bone marrow of patients with myelodysplastic syndrome and erythroleukemia, which are preneoplastic and neoplastic conditions, respectively; megaloblastosis in these two latter conditions are not reversed by therapy with vitamin $B_{12}$ and folate $[1,7,9]$. Irrespective of their causes, megaloblastosis in all of these conditions as stated above are cytomorphologically similar, character- 
Fig. 8. A cartoon showing metabolic interrelations between vitamin $\mathrm{B}_{12}$ and folate with special reference to the de novo and salvage pathways of thymidylate synthesis $(\mathrm{dUMP} \rightarrow \mathrm{dTMP})$.

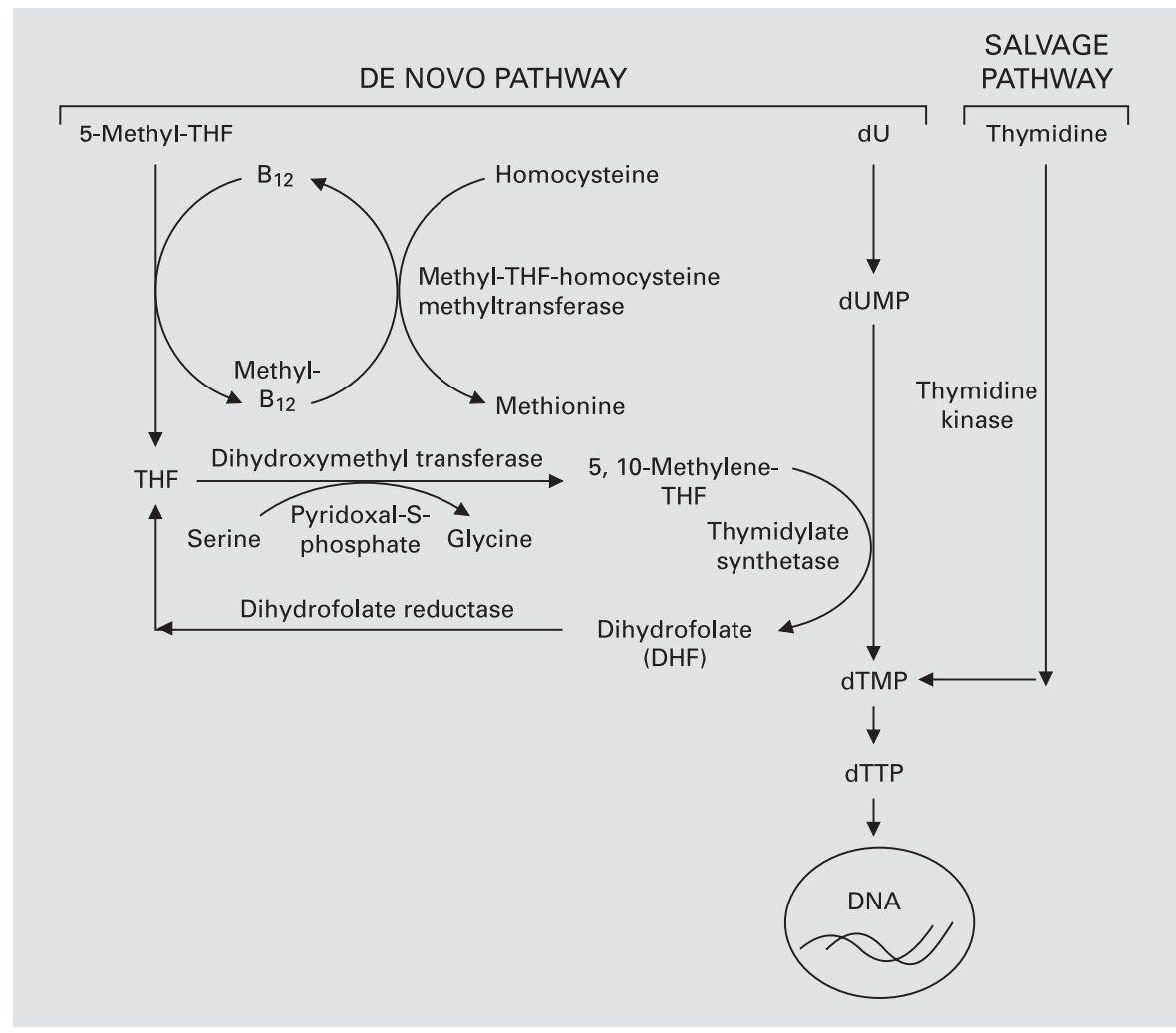

ized by the open lacy pattern and spongy nuclear chromatin in both light and transmission electron microscopic observations. The distinctive structural changes in the chromatin of megaloblasts in patients with vitamin $B_{12}$ and folate deficiency were found to be associated with several structural abnormalities of individual chromosomes such as elongation and despiralization (unwinding) of chromosomes. These may cause a defect in packaging chromosomes inside the cells, possibly impairing cell growth and cell functions, although no significant abnormalities of chromosome number were observed and the modal chromosome number remained 46 (diploid) with no consistent or significant aneuploidy [19, 27-29]. It has been suggested that the cytomorphological and cytogenetic changes in megaloblastic anemia may be an expression of deranged cellular DNA synthesis [7-12].

Cellular DNA comprises four deoxynucleotide triphosphate building blocks, namely deoxyadenosine triphosphate, deoxyguanosine triphosphate, deoxycytosine triphosphate and dTTP. In the double-stranded DNA helix, adenine pairs with thymine $(\mathrm{A}=\mathrm{T})$ and guanine with cytosine $(\mathrm{G}=\mathrm{A})$. The base composition of DNA extracted from megaloblastic and normoblastic bone marrows has been shown to be similar and the ratios of A:T and G:C are close to unity [30]. The synthesis of DNA in replicating cells is regulated by a number of reaction loops some of which are directly or indirectly dependent on the availability of folate coenzymes and vitamin $\mathrm{B}_{12}$ (fig. 8). The relevant and important reactions include: homocysteine to methionine interconversion, which requires methylcobalamin $\left(\mathrm{CH}_{3}-\mathrm{B}_{12}\right)$ as an essential cofactor; in this reaction, 5-methyl-THF, the predominant form of plasma folate which is metabolically inactive, is also converted into an active compound, THF. This latter compound is, in turn, converted into 5,10-methylene-THF, which is an essential coenzyme in converting dUMP to dTMP by the enzyme thymidylate synthase. The dU suppression test provides a sensitive quantitative assessment of megaloblastic anemia and can also reveal the type of vitamin deficiency causing this anemia. This test is capable of distinguishing megaloblastosis associated with myelodysplastic syndrome and erythroleukemia from that resulting from deficiency of vitamin $B_{12}$ and folate, since the $\mathrm{dU}$ suppression test is normal in the former two conditions, whereas it is abnormal in deficiency of vitamin $\mathrm{B}_{12}$ and folate. These observations also militate against the 
hypothesis of megaloblastosis being an expression of deranged cellular DNA synthesis, regardless of the causes [1, 7-9]. Megaloblastic changes in erythroleukemia and myelodysplastic syndrome are possibly caused by mechanisms unrelated to the dU suppression abnormality [18]. The results of our studies on experimental folate deficiency in rhesus monkeys and Wistar strain rats are of considerable interest and relevant to the possible relationship between deranged DNA synthesis and the development of megaloblastosis. Both rhesus monkeys and rats, when made folate deficient, developed an abnormality in DNA synthesis as indicated by an abnormal dU suppression test, but only folate-deficient monkeys developed frank megaloblastosis, whereas folate-deficient rats remained unequivocally normoblastic. These observations support the concept that while DNA synthetic abnormality as revealed by $\mathrm{dU}$ suppression test is a sensitive index of folate and/or vitamin $\mathrm{B}_{12}$ deficiency, this abnormality alone may not be the sole molecular event leading to megaloblastosis. Megaloblastic changes in the bone marrow also occur following chemotherapy with several drugs that impair DNA synthesis; but the precise molecular mechanisms underlying the development of megaloblastosis in those circumstances have not been adequately investigated.

The elongation and despiralization of chromosomes in replicating megaloblasts [19, 27-29] appear to reflect their characteristic cytomorphological features in the interphase nuclear chromatin as observed in light and transmission electron microscopy. The results of our studies on electron microscopic configuration of DNA fibers extracted from megaloblastic and normoblastic bone marrows appear to provide additional data on molecular events associated with megaloblastosis. The extraction of histones from DNA of normal bone marrow cells by treatment with proteinase $\mathrm{K}$ during extraction procedure made the DNA fibers lose the knotted and spiral pattern, and appear straight with bundles of fibers running parallel as observed by transmission electron microscopy; on the other hand, DNA fibers extracted from megaloblastic bone marrows, even when untreated by proteinase $\mathrm{K}$, appeared relatively straight and devoid of knots and without wavy or spiral pattern. These findings suggest that the DNA extracted from megaloblastic bone marrows even without proteinase K treatment had a markedly decreased histone content as compared to DNA from normoblastic bone marrows (fig. 7a-d). These assumptions were further supported by our studies on histone biosynthesis. The results of incorporation of ${ }^{3} \mathrm{H}$-tryptophan, ${ }^{3} \mathrm{H}$-lysine and ${ }^{3} \mathrm{H}$-arginine into nuclear histone in short-term cul- tures of megaloblastic as well as control (normoblastic) bone marrows provided a differential profile (table 6). Biosynthesis of histones in megaloblastic bone marrows was significantly lower than in control bone marrows or in bone marrows of patients with iron deficiency anemia. This reduction was more marked in respect of incorporation of ${ }^{3} \mathrm{H}$-arginine than in respect of ${ }^{3} \mathrm{H}$-lysine and ${ }^{3} \mathrm{H}$ tryptophan. Nuclear histones play a significant role in coiling and spiralization of chromosomes, and considerable attention has generally been focused on the role of these proteins in the regulation of the structure of chromosomes in replicating cells and chromatin in the interphase nucleus. There are several species of histones, some of which are lysine rich $\left(\mathrm{H}_{1}, \mathrm{H}_{2} \mathrm{~A}, \mathrm{H}_{2} \mathrm{~B}\right)$ and others are arginine rich $\left(\mathrm{H}_{3}, \mathrm{H}_{4}\right)$. The nuclear chromatin is made up of repeating units (nucleosomes), each containing approximately $200 \mathrm{bp}$ of DNA and two each of $\mathrm{H}_{2} \mathrm{~A}, \mathrm{H}_{2} \mathrm{~B}$, $\mathrm{H}_{3}$ and $\mathrm{H}_{4}$. Most of the DNA molecules are winded around the outside of a core of histones - the remaining DNA, the linker DNA, joins adjacent nucleosomes - and contribute to the flexibility of the chromatin network. Thus, a chromatin is delicately joined to a chain of nucleosomes rather like beads on a string [21-23]. Changes in the composition of histones have been described in developing sperms [22] and duck erythroblasts [24], and in both instances, arginine-rich histones have been shown to increase as a function of cell maturation. The decreased synthesis of predominantly arginine-rich histones in the megaloblasts may be related to their impaired nuclear maturation and asynchrony of nuclear cytoplasmic development. It may be suggested that cytomorphological changes of megaloblastosis may be closely related to an imbalance in the molecular species of histones, which in some instances (as in vitamin $\mathrm{B}_{12}$ and folate deficiency) may interact with slowly synthesizing DNA in the replicating cells. The reduced synthesis of particularly arginine-rich histone may be a common denominator of biochemical events in clinical and hematological conditions associated with megaloblastic transformation of erythropoiesis. In recent years, several groups of investigators observed significant associations of specific histone patterns, acetylase/deacetylase activities with cell cycle changes, and apoptosis in many neoplastic cell models $[31,32]$. Intranuclear mechanisms that signal apoptosis after DNA damage overlap with those that initiate cell cycle arrest and disturb cell cycle checkpoints [32, 33]. Interactions between these nuclear events and apoptotic processes may cause genomic instability in other cell systems as well $[33,34]$. Naturally occurring or synthetic inhibitors of histone deacetylases can cause cell cycle ar- 
Fig. 9. A cartoon showing the postulated molecular basis of development of megaloblastosis.

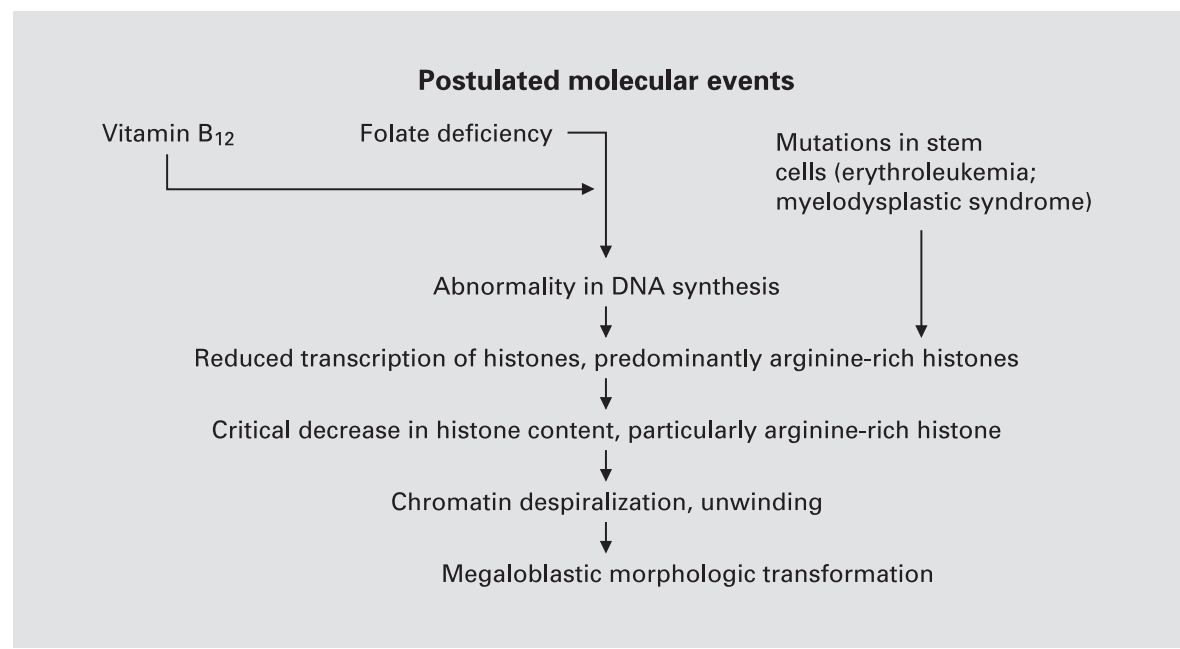

rest, differentiation and apoptosis in neoplastic cells opening a door to explore newer cancer chemotherapy strategies $[34,35]$. It is possible that changes in nuclear histones coupled with altered chromatin may also impair regulation of cell cycle checkpoints promoting apoptosis in megaloblastic bone marrows as suggested by several recent studies [36-39]. Recently, it has been reported that the nuclear histone content of bone marrows in lower mammalian species such as rats is much higher than that of higher mammalian species such as rhesus monkey [40]. This is believed to be a phylogenetic characteristic. When folate deficiency was induced in monkeys, their bone marrow developed florid megaloblastic transformation, and this was associated with marked reduction of particularly arginine-rich histones, but folate-deficient rats did not develop megaloblastic transformation, although DNA synthesis was impaired as indicated by abnormal dU suppression values. This can be explained by the initially high histone content in the bone marrow cells in the rats, which was not sufficiently reduced even in established folate deficiency to reach a critically low level required for megaloblastic transformation [36]. A postulated scheme of molecular events in the development of megaloblastosis is given in figure 9 .

\section{Conclusions}

Cytomorphological features of megaloblasts in light and electron microscopy and the chromosomal pattern suggest that elongation, despiralization and uncoiling of chromosomes were related to the finely stippled lacy pat- tern of the nuclear chromatin which distinguishes them from normoblasts. DNA synthetic abnormality as revealed by abnormal dU suppression test in vitamin- $\mathrm{B}_{12^{-}}$ and folate-deficient megaloblastic anemia is not a consistent molecular event underlying the development of megaloblastosis in all clinical and hematological disorders in which megaloblastic changes are observed (e.g. myelodysplastic syndrome and erythroleukemia). Nuclear proteins, particularly histones, are known to play a significant role in causing spiralization, twisting or coiling of chromosomes in the replicating cells and in the condensation of nuclear chromatin in the interphase. The reduced biosynthesis of histones particularly of arginine-rich histones as shown in 'megaloblastic' bone marrows irrespective of their causes appears to be a common denominator of molecular events associated with the development of megaloblastosis.

\section{Acknowledgements}

This work was supported by Kuwait University Research Grant No. MG 011 and the Institute of Immunohematology, Mumbai, India. The authors highly appreciate the excellent work done and the painstaking care taken by Mr. James Luke, Secretary, Department of Pathology, in preparing the manuscript. 


\section{References}

1 Chanarin I: The Megaloblastic Anaemia, ed 3. Oxford, Blackwell Scientific Publications, 1990, pp 315-331.

2 Wills L: Treatment of pernicious anaemia of pregnancy and 'tropical anaemia' with special reference to yeast extract as a curative agent. Br Med J 1931;1:1059-1064.

-3 Wills L: Treatment of pernicious anaemia, nutritional macrocytic anaemia and tropical sprue. Blood 1948;3:36-56.

4 Chatterjea JB: Nutritional megaloblastic anaemia in tropical zones. Proc 11 th Congr Int Soc Hematol, Sidney, 1966, pp 120-132.

5 Das KC: Nutritional megaloblastic anaemia. Proc Symp Nutr Anemias, Plenary Sess 2, Meet Asian Pacific Div, Int Soc Hematol, Melbourne, 1971, pp 11-13.

-6 Herbert V: The five possible causes of all nutrient deficiency. Aust NZ J Med 1972;1:69-72.

7 Das KC, Herbert V: Vitamin $B_{12}$-folate interrelations. Clin Haematol 1976;5:997-725.

8 Herbert V: The Megaloblastic Anemias, ed 1. New York, Grune and Stratton, 1959, p 1.

9 Lee RG: Megaloblastic anemias: Disorders of impaired DNA synthesis; in Lee RG, Foester J, Lukens J, Parakevas JP, Rodgers GM (eds): Wintrobe's Clinical Hematology, ed 10. Baltimore, Williams \& Wilkins, 1999, pp 941978.

10 Das KC, Hoffbrand AV: Lymphocyte transformation in megaloblastic anaemias. Morphology and DNA synthesis. Br J Haematol 1970; 19:459-468.

11 Das KC, Herbert V: The lymphocyte as a marker of past nutritional status. Persistence of abnormal lymphocyte deoxyuridine (dU) suppression test and chromosomes in patients with past deficiency of folate and vitamin $\mathrm{B}_{12}$. Br J Haematol 1978;38:219-223.

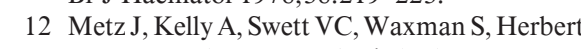
$\mathrm{V}$ : Deranged DNA synthesis by bone marrow from vitamin $\mathrm{B}_{12}$-deficient humans. Br J Haematol 1968;14:575-592.

13 Mohanty D, Das KC: Effect of folate deficiency on the reproductive organs of female Rhesus monkeys: A cytomorphological and cytokinetic study. J Nutr 1982;112:1505-1576.

14 Johnson EM, Nelson MM, Monie IN: The composition of folate-deficient diet for rats. Anat Rec 1963;146:215.

15 Dacie JV, Lewis SM: Practical Haematology, ed 8. London, Churchill Livingstone, 1995, pp $49-143$.
16 Das KC, Herbert V: In vitro DNA synthesis by megaloblastic bone marrow: Effect of folates and cobalamins on thymidine incorporation and de novo thymidylate synthesis. Am J Hematol 1989:31:11-20.

17 Das KC, Manusselis C, Herbert V: In vitro DNA synthesis by bone marrow cells and PHA-stimulated lymphocytes. Suppression by non radioactive thymidine of the incorporation of ${ }^{3} \mathrm{H}$-deoxyuridine into DNA: Enhancement of incorporation when inadequate vita$\min \mathrm{B}_{12}$ and folate is corrected. $\mathrm{Br} \mathrm{J}$ Haematol 1980;44:51-63.

18 Das KC, Garewal G, Mohanty D: Derangement of DNA synthesis in erythroleukemia. Normal deoxyuridine suppression and impaired thymidine incorporation in bone marrow culture. Acta Haematol 1980;64:121134.

19 Das KC, Mohanty D, Garewal G: Cytogenetics in nutritional megaloblastic anaemia: Prolonged persistence of chromosomal abnormalities in lymphocytes after remission. Acta Haematol 1986;76:146-154.

20 Sambrook J, Fritsch EF, Maniatis J: Molecular Cloning: A Laboratory Manual. New York, Cold Spring Harbor Laboratory Press, 1989, pp 1-25.

21 Murray K: The acid extraction of histones from calf thymus deoxyribonucleoprotein. $\mathrm{J}$ Mol Biol 1966; 15:409-419.

-22 Das KC, Kaufman RP, Gay H: Autoradiographic evidence of synthesis of an argininerich histone during spermatogenesis in $\mathrm{Dro}-$ sophila melanogaster. Nature 1964;204: 1008-1009.

23 Tidwell T, Allfrey VF, Mirsky AE: The methylation of histone during regeneration of the liver. J Biol Chem 1968;243:707-715.

24 Gershey FL, Halett GW, Vidali G, Allfrey VG: Chemical studies on histone methylation. Evidence for the occurrence of 3-methyl-histidine in avian erythrocyte histone fraction. J Biol Chem 1969;244:4871-4877

25 Longo DL, Herbert V: Radioassay for serum and red cell folate. J Lab Clin Med 1976;87: 138-151.

26 Das KC, Manusselis, Herbert V: Determination of vitamin $B_{12}$ (cobalamin) in serum and erythrocytes by radioassay and of holo-transcobalamin II ( holo-TC-II) and holo-haptocorrin (holo-TC1 and III) in serum by adsorbing holo-TC-II on microfine silica. J Nutr Biochem 1991;2:455-463.

27 Kiossoglou, KA, Mitus WJ, Dameshek W: Chromosomal aberrations in pernicious anemia. Study of three cases before and after therapy. Blood 1965;5:662-682.
28 Heath CW: Cytogenetic observations in vitamin $\mathrm{B}_{12}$ and folate deficiency. Blood 1966;27: 800-815.

29 Das KC: Nutritional megaloblastosis. Symp Nutr Anaemias. Proc Second Congr Asian Pacific Div, Int Soc Haematol, New Delhi, 1976, pp 14-15.

30 Hoffbrand AV, Pegg AE: Base composition of normal and megaloblastic bone marrow DNA. Nat New Biol 1972;235:187-188.

31 Khobta A, Carlo-Stella C, Capranico G: Specific histone patterns and acetylase/deacetylase activity at the breakpoint-cluster region of the human MLL gene. Cancer Res 2004;64:26562662.

32 Zhao J: Coordination of DNA synthesis and histone gene expression during normal cell cycle progression and after DNA damage. Cell Cycle 2004;3:695-697.

33 Norbury CJ, Zhivolovsky B: DNA damageinduced apoptosis. Oncogene 2004;23:27972808.

34 Wang C, Fu M, Pestell RG: Histone acetylation/deacetylation as a regulator of cell cycle gene expression. Methods Mol Biol 2004;241: 207-216.

-35 McLaughlin F, La Thangue NB: Histone deacetylase inhibitors open new doors in cancer therapy. Biochem Pharmacol 2004;68: 1139-1144.

-36 Ingram CF, Davidoff AN, Marais F, Sherman GG, Mendelow BV: Evaluation of DNA analysis for evidence of apoptosis in megaloblastic anaemia. Br J Haematol 1997;96:576-583.

37 Koury MJ, Price JO, Hicks GG: Apoptosis in megaloblastic anemia occurs during DNA synthesis p53-independent, nucleoside-reversible mechanism. Blood 2000;96:3249-3255.

$38 \mathrm{Gu}$ L, Wu J, Qiu L, Jennings CD, Li GM: Involvement of DNA mismatch repair infolate deficiency-induced apoptosis small star, filled. J Nutr Biochem 2002;13:355-363.

39 Li GM, Presnell SR, Gu I: Folate deficiency, mismatch repair-independent apoptosis and human disease. J Nutr Biochem 2003;14:568575 .

40 Das KC, Easow SK, Jadaon M, Das M, Mohanty D: The development of megaloblastosis is a species-restricted phenomenon. 9th Annu Health Sci Poster Conf, Kuwait, April 19-21, 2004, p 284. 